\section{Цитування:}

Кундис Р. Ю., Никорович І. Ю. До питання удосконалення майстерності акордеоністаакомпаніатора на прикладі львівських хореографічних колективів. Вісник Національної академії керівних кадрів культури і мистецтв : наук. журнал. 2021. № 2. С. 234-237.

Kundys R., Nykorovych I. (2021). On the issue of improving the skills of the accordionistaccompaniator on the example of Lviv choreographic groups. National Academy of Culture and Arts Management Herald: Science journal, 2, 234-237 [in Ukrainian].

\author{
Kundys Ruslan, \\ Candidate of Arts, \\ associate professor of the Department of Stage \\ Production and Choreography \\ Lviv Ivan Franko National University \\ ORCID: https://orcid.org/0000-0002-6374-4811 \\ ruslan.kundys@lnu.edu.ua \\ Nykorovych Ivan, \\ assistant of the Department of Stage \\ Production and Choreography \\ Lviv Ivan Franko National University \\ ORCID: https://orcid.org/0000-0001-6610-5823 \\ ivan.nykorovych@lnu.edu.ua
}

\title{
ON THE ISSUE OF IMPROVING THE SKILLS OF THE ACCORDIONIST- ACCOMPANIATOR ON THE EXAMPLE OF LVIV CHOREOGRAPHIC GROUPS
}

The purpose of the article. It consists in identifying and classifying the features, tasks, forms of cooperation of representatives of this specialty with choreographic groups of Lviv. The methodology consists in the complex application of historical, source and comparative methods. This methodological approach allows to reveal and analyzing the specifics of the interaction of the leaders of the leading Lviv choreographic groups with accordionists in comparison with a set of tools and creative concepts. The scientific novelty of the article is determined by the implementation of the first special study of the features, tasks, forms of cooperation of accordionists with choreographic groups of a particular region. Conclusions. The most prominent representatives among the musicians of this specialty in the choreographic groups of Lviv have been singled out, their achievements and reaching the international level have been specified. The requirements of professional training of an accordionist to perform these functions are specified. period.

Key words: accordion accompanist; professional training; choreographic team; creative concept; pre-concert

Кундис Руслан Юрійович, кандидат мистецтвознавства, доцент кафедри режисури та хореографіі Львівського начіонального університету імені Івана Франка; Никорович Іван Юрійович, асистент кафедри режисури та хореографії Львівського наџіонального університету імені Івана Франка

До питання удосконалення майстерності акордеоніста-акомпаніатора на прикладі львівських хореографічних колективів

Мета роботи - виявити та класифікувати особливості, завдання, форми співпраці представників означеної спеціальності з хореографічними колективами Львова. Методологія дослідження полягає в комплексному застосуванні історичного, джерелознавчого і компаративного методів. Зазначений методологічний підхід дозволяє розкрити та піддати аналізу специфіку взаємодії керівників провідних львівських хореографічних колективів з баяністами-концертмейстерами в порівнянні комплексу засобів і творчих концепцій. Наукова новизна роботи визначається реалізацією першого спеціального дослідження особливостей, завдань, форм співпраці баяністів-концертмейстерів 3 хореографічними колективами конкретного регіону. Висновки. Виокремлено найвизначніших представників серед музикантів цієї спеціальності у хореографічних колективах Львова, конкретизовано їх здобутки й вихід на міжнародний рівень. Конкретизовано вимоги фахової підготовки акордеоніста для виконання даних функцій.

Ключові слова: баяніст-концертмейстер; фахова підготовка; хореографічний колектив; творча концепція; перед концертний період.

Relevance of the research topic. The importance of the role of the accompanist in the activities of the choreographic ensemble is due to a range of factors, features, and functions both in the process of concert performances and in the rehearsal period. Mostly although at the present stage dance groups use phonograms, or accompaniment of an orchestra-ensemble, the relevance of the accompaniment of the accompanist (pianist, accordionist, accordionist) is

(C) Kundys R., 2021

(C) Nykorovych I., 2021 
still undeniable given the uniqueness of its functions and potential for inclusion in the preconcert process. However, given the wide representation of choreographic ensembles in Lviv, there is no special study of the features, tasks, forms of cooperation of accordionists with groups in the region.

Analysis of research and publications. In the scientific literature, concertmaster's functions are most often considered from the standpoint of piano performance and pedagogy. Researcher of the concertmaster's profession in the course of nurturing professional pianist Julia Nebunu, based on the work of S. Savary, E. Kubantseva, A. Lublinskiy, E. Shenderovich, notes: «Analysis of the specifics of the professions of accompanist and accompanist allows us to note that the professional functions of the accompanist of the XXI century have expanded significantly. Today, the accompanist must not only have a good instrument, but also have the ability to work with soloists, help them interpret musical material, and therefore, he must have not only performance skills but also psychological and pedagogical sense, have a developed artistic and aesthetic essence. The formation of professional skills of the accompanist takes place in secondary special educational institutions of art. Therefore, the further study requires the introduction of innovative forms of work aimed at training a highly competent accompanist who meets modern musical and performance requirements» $[5,180]$.

The accordion and accordion occupy their own niche in concertmaster practice, as these instruments are distinguished by, among other things, ease and convenience in transportation, a wide range of sounds despite their small size, the orchestral richness of timbre colors, and harmony of sound. These qualities of these instruments not only distinguish them from others used in concertmaster but also arouse scientific interest in the activities of accordionists, who skillfully use them in concertmaster practice.

However, if the activities of some famous dance groups of Ukraine and their organizers and leaders conducted explorations [1], reviews, reviews [4], essays, data from Internet resources, a number of studies conducted on the specifics of the work of pianists-accompanists [5], the agreement or, conversely, the antinomy of the positions of concertmasters-performers on accordion or accordion in cooperation with choreographic groups is considered extremely sparingly and in passing. These issues are considered in the works and methodological recommendations of practitioners [1], works on the Lviv Bayan School as a whole [2; 3], and its individual prominent personalities [6]. For these reasons, the purpose of this article is to reveal, identify and classify the features, tasks, forms of cooperation of dance group leaders and accordionists.

Presenting main material. The fact of constant cooperation with accordionistsaccordionists as accompanists is observed not only in children's groups, where the initial phases of training are especially dependent on flexible and productive interaction with the teacherchoreographer but also in leading domestic ensembles. Thus, in the interview with the artistic director of the ensemble Myroslav Vantukh, the multifaceted cooperation with concertmastersaccordionists and going beyond other forms of the ensemble was clearly outlined in the interview with the ensemble named after Pavel Virskyy: «First, we must name our chief conductor Alexander Dmitrievich Cheberko. He used to be the artistic director and conductor of the Donbass song and dance ensemble ... the accordion just sings in his hands. Alexander Dmitrovich not only conducts the orchestra but also writes music ... The orchestra under his direction has twice performed with great success in Spain and Portugal (with classical repertoire) ... The conductor feels perfectly at what pace each soloist is able to perform his tricks ... I can't help but mention with gratitude the accordionists - very experienced Alexander Khrustevich, brothers Ruslan and Bohdan Pirog, Alexander Ponomarev»» [4].

Representation of accordionists in the activities of dance groups of Lviv and the Lviv region is quite significant. It can be considered on the examples of specialists in this field in such groups as the Honored Dance Ensemble of Ukraine "Yunist" of the Lviv State Palace of Aesthetic Education of Students, vocal and choreographic ensemble "Veseli cherevychky", Exemplary vocal and choreographic ensemble "Vikrutasyky", Honored Vocal and Choreographic Ensemble of Ukraine "Galychyna", folk song and dance ensemble "Cheremosh" of Lviv National University named after Ivan Franko and folk dance ensemble "Polonyna" of the National Forestry University of Ukraine, groups of Lviv College of Culture and Arts and many others. But due to the large number of accordionists who once collaborated with these groups, it is impossible to analyze the activities of each in one article. Therefore, we consider it necessary to dwell on the most prominent representatives of the accordion accompaniment of the Lviv region, whose activities laid the foundations for the formation of the skill of the accordionist and 
became an example for future generations of representatives of this specialty.

The brightest figure in the context of this study is Stanislav Khytryak (1947-2002) accordionist-soloist, accompanist, arranger, who from the late 1970s worked in Lviv region as concertmaster in the House of Culture "Lvivkhimsilhospmash" and the Palaces of Railway Culture in the folk dance ensemble "Spring" (director G. Nazarenko). From 1980 to 2001 he was the concertmaster of the choreography department of the Lviv School of Culture, and from 1982 the concertmaster, arranger, and artist of the orchestra of the Honored Dance Ensemble of Ukraine "Yunist" (Director - People's Artist of Ukraine Mikhail Vanovskyy). He is the author of dozens of orchestral compositions for Ukrainian and foreign dance groups ${ }^{1}$. The tours made with the band "Youth" cover Argentina, Greece, Italy, Poland, Sweden (in collaboration with this team work Vladimir Mukha - a student of D. Oberyukhtin (works since 1989), and co-author of this exploration Ruslan Kundys - graduate of the accordion class of A. Dushniy). The group organized a children's school of folk dance, created a folk dance ensemble "Carpathians" (leader Honored Artist of Ukraine Vasyl Semen), in which young men and women gain stage experience, from which the main staff of "Yunist" is replenished.

Experienced accordionist S. Khytryak, in collaboration with the outstanding choreographer Oleg Goldrych, co-authored the publication "Musical Reader for Folk and Stage Dance Lessons" [1], thus recording the artistic result of the long-term joint work successfully tested by the concert dancer. According to the authors, this musical textbook is a textbook for teachers and accompanists of art schools of Ukraine I-IV level of accreditation. It is designed for folk dance lessons, addressed to both specialists and amateurs of folk choreography, employees of choreographic groups, teachers of children's art schools, high schools and centers of children's art. In particular, in this work there is a section "Training exercises", which contains a description of the characteristic training, its impact on individual joints and muscles, provides useful recommendations based on practical experience [1]. For each exercise, several variants of different in nature accordion music are offered. The formation of the collection on the basis of detailed practical testing is a particularly valuable and important factor.

The artist demonstrated the experience gained in the process of work at a wide social and artistic level: S. Khytryak was the concertmaster of the summer school for dance group leaders "Fort Qu'Appelle" in Regina (Canada), participated in the organization of international choreographic seminars in Lviv and abroad (in France, Croatia, Poland, Canada).

Another prominent representative of the accordion accompaniment of the Lviv region is the Honored Worker of Culture of Ukraine (1989) Petro Rachynskyy (1949) - soloist, arranger, teacher, graduate of M. Oberyukhtin's class. From his student years, the musician began to work as an accompanist (since 1968), and later as a leader (from 1975 to the present) of orchestras and ensembles of folk instruments, including and the orchestra of the vocal and choreographic ensemble "Galychyna" (artistic director and chief choreographer of the ensemble - Honored Worker of Culture of Ukraine Oleksiy Bobkiv).

As a soloist-accordionist, accompanist, leader of the instrumental group of this dance group P. Rachynskyy on tour covers a large list of European countries: England (1992, 2004); Belgium (1991, 1998); Bosnia and Herzegovina (2000); Denmark (2000, 2003); Italy (1997); Luxembourg (2002); The Netherlands (1988, 2003); Germany (1999, 2001); Serbia and Montenegro (1994); France (1969, 1993, 1999, 2000); The Czech Republic (2002); Yugoslavia (1990); Australia (1991); Canada (1989, 1993); USA $(1987,1988,1989,1990,1993,1995,2005)$ [6]. The musician is the creator of the performing repertoire: during the thirty-year period of cooperation with the orchestra of the ensemble "Galychyna" he performed almost all the orchestrations and arrangements of dances that represent various subjects of Western Ukraine ${ }^{2}$. In them, as noted by the researcher of the maestro B. Pitz: «...the breadth and universalism of P. Rachynskyy's talent became clear - the accordion in his hands reproduces a huge range and the subtlest shades of vocal and instrumental, folk, opera and chamber music, he has access to compositions of various styles, forms and genres» $[6,180]$. Choreographic programs of the ensemble were recorded by Lviv Television, the ensemble took part in periodical programs of Moscow television "Wider Circle", "Anu-ka, girls!" and Interclub of Ukrainian television, "Ukrtelefilm" made a documentary about him, "Carpathian Patterns". Separately with the ensemble orchestra, the musician recorded two discs in 1999 and $2004^{3}$.

Conclusions. Thus, from the above list of bright personalities we see that the professional training of the accompanist of each of the considered choreographic groups of Lviv requires 
not only skillful mastery of their own instrument and operation of a large base of various genres of repertoire. Also requires skills of stylistic and genre improvisation, orientation in special choreographic terminology, ability for flexible cooperation with the choreographer, understanding of training tasks and stage specifics of the performance process. Functions of accordionists include: musical and didactic support of pre-concert training of the group, participation in ensembles (orchestras) during concert and touring performances, combination of roles of accompanist and instrumental group leader, involvement in the formation of repertoire in the form of translations, orchestrations and original specific performance needs, collaboration in video and audio recordings. In close cooperation with the teacher-choreographer, the accompanist forms a training rehearsal base, focused on the appropriate level of preparation and long-term tasks, crystallizes intonation, tempo, dynamic, accent drama of each work, develops the optimal scale of sections and preparation. Hence - going beyond the accompaniment to cooperation, co-creation in the union of choreographic and musical principles. Developments are recorded in the form of didactic collections, manuals, where choreographic and musical components are closely related, and the exchange of achievements is possible through the analysis of concert performances, participation in the competition-festival movement, choreographic seminars, etc., their consideration and comparison are promising areas research.

\section{Notes}

1 In particular, for the honored dance ensemble "Yunist": "Hopak", "Cossack Duma", "On the Zaporozhian Sich", "Bukovynian Holiday", "Vital", "Thought about Ukraine", "Carpathian Patterns", "Bubnarsky", "Ukrainian Rhapsody", "Gordilyanka" and others.

2 Hutsul region is represented by dances "Arkan", "Dance of the Call", "Pivtorak", "Sopilka from Verkhovyna", Bukovyna - "Voloshka", "Skakunets", Pokuttya - "Golubka", "Serbin", Zakarpattia - "Digital", Central Ukraine "Cossack", "Hopak", "Congratulatory dance".

3 CD Ref: HALY200006. «Halyczyna. Ukrainian Folk Orchestra. Directed by Petro Rachynskyy». Vocal and instrumental works of Ukrainian composers and folk songs. - France, 1999; CD, "Carpatian Folk Music". Instrumental works performed by the orchestra of the Honored Vocal and Choreographic Ensemble, "Galychyna". Head P. Rachynskyy. - Lviv, 2004.

\section{References}

1. Goldrych, O., Khitryak, S. (2003). Music textbook for lessons of folk dance. Lviv, Krai. [in Ukrainian].

2. Dushniy, A. (2009). Lviv folk instrumental traditions. Our culture: Bulletin of the Starosambir People's House. Part 2. p. 3. [in Ukrainian].

3. Dushniy, A., Pyts, B., Shafeta, V. (2013). The young generation of accordionists-performers of Ukraine. Current issues of the humanities. Iss. 5. pp. 94-103. [in Ukrainian].

4. Zilina, L. (2010). Hopak is not too much ... March 6 and 7 Ensemble. Pavel Virsky will give concerts dedicated to the 105th anniversary of the birth of its famous founder. Day. March 4. [in Ukrainian].

5. Nebunu, Y. (2006). On the problem of understanding the profession of accompanist in the artistic and aesthetic perspective of musical performance. Problems of modern pedagogical education: coll. science. wash. Iss. 11. Part 2: Series: Pedagogy and Psychology. Yalta: RVV KSU. pp. 178184. [in Ukrainian].

6. Pyts, B. (2006). Peter Rachynskyy: touches to the creative portrait. Academic folk-instrumental art and vocal schools of Lviv region: collection. mate. scientific-practical conf. Drohobych: Pósvit. pp. 176182. [in Ukrainian].

\section{Jimepamypa}

1. Голдрич О., Хитряк С. Музична хрестоматія для уроків народно-сценічного танцю. Львів, Край. 2003. 232 с.

2. Душний А. Львівські народноінструментальні традиції. Наша культура: Вісник Старосамбірського народного дому. Ч. 2. 2009. Квітень С. 3.

3. Душний А., Пиц Б., Шафета В. Молода генерація авторів-виконавців баяністівакордеоністів України. Актуальні питання гуманітарних наук. Вип. 5. 2013. С. 94-103.

4. Жиліна Л. Гопака забагато не буває... 6 і 7 березня Ансамбль ім. Павла Вірського дасть концерти, присвячені 105-річчю від дня народження свого славетного засновника. День. 2010. 4 березня.

5. Небуну Ю. До проблеми осмислення професії концертмейстера в художньо-естетичному ракурсі музичного виконавства. Проблеми сучасної педагогічної освіти: зб. наук. праць. Вип. 11, ч. 2 : Серія : Педагогіка і психологія. Ялта: РВВ КГУ, 2006. C. 178-184.

6. Пиц Б. Петро Рачинський: штрихи до творчого портрета. Академічне народноінструментальне мистецтво та вокальні школи Львівщини: зб. мат. наук.-практ. конф. Дрогобич: По́світ, 2006. С. 176-182.

Стаття надійшла до редакиії 03.03.2021

Отримано після доопраџювання 29.03.2021

Прийнято до друку 02.04.2021 